\title{
Long-Term Outcomes and Practical Considerations in the Pharmacological Management of Tyrosinemia Type 1
}

\author{
Willem G. van Ginkel ${ }^{1}$ - Iris L. Rodenburg ${ }^{2}$ - Cary O. Harding ${ }^{3}$. Carla E. M. Hollak ${ }^{4}$ M. Rebecca Heiner-Fokkema ${ }^{5}$. \\ Francjan J. van Spronsen ${ }^{1}$
}

Published online: 31 October 2019

(c) The Author(s) 2019

\begin{abstract}
Tyrosinemia type 1 (TT1) is a rare metabolic disease caused by a defect in tyrosine catabolism. TT1 is clinically characterized by acute liver failure, development of hepatocellular carcinoma, renal and neurological problems, and consequently an extremely poor outcome. This review showed that the introduction of 2-(2-nitro-4-trifluoromethylbenzoyl)-1,3-cyclohexanedione (NTBC) in 1992 has revolutionized the outcome of TT1 patients, especially when started pre-clinically. If started early, NTBC can prevent liver failure, renal problems, and neurological attacks and decrease the risk for hepatocellular carcinoma. NTBC has been shown to be safe and well tolerated, although the long-term effectiveness of treatment with NTBC needs to be awaited. The high tyrosine concentrations caused by treatment with NTBC could result in ophthalmological and skin problems and requires life-long dietary restriction of tyrosine and its precursor phenylalanine, which could be strenuous to adhere to. In addition, neurocognitive problems have been reported since the introduction of NTBC, with hypothesized but as yet unproven pathophysiological mechanisms. Further research should be done to investigate the possible relationship between important clinical outcomes and blood concentrations of biochemical parameters such as phenylalanine, tyrosine, succinylacetone, and NTBC, and to develop clear guidelines for treatment and follow-up with reliable measurements. This all in order to ultimately improve the combined NTBC and dietary treatment and limit possible complications such as hepatocellular carcinoma development, neurocognitive problems, and impaired quality of life.
\end{abstract}

Francjan J. van Spronsen

f.j.van.spronsen@umcg.nl

1 Department of Metabolic Diseases, Beatrix Children's Hospital, University Medical Center Groningen, University of Groningen, Hanzeplein 1, 9700 RB Groningen, The Netherlands

2 Department of Dietetics, University Medical Center Groningen, University of Groningen, Groningen, The Netherlands

3 Department of Molecular and Medical Genetics, Oregon Health \& Science University, Portland, USA

4 Deparment of Endocrinology and Metabolism, Amsterdam University Medical Center, University of Amsterdam, Amsterdam, The Netherlands

5 Department of Laboratory Medicine, University Medical Center Groningen, University of Groningen, Groningen, The Netherlands

\section{Key Points}

Treatment with 2-(2-nitro-4-trifluoromethylbenzoyl)1,3-cyclohexanedione (NTBC) has been found to be generally safe and has clearly improved treatment and outcomes for patients with tyrosinemia type 1 .

The long-term risks for complications associated with tyrosinemia type 1 or treatment with NTBC are not yet fully known and therefore strict follow-up is necessary.

Future challenges include the development of uniform guidelines for treatment and follow-up, and weighing the risks, challenges, and costs of existing and alternative strategies for the treatment of tyrosinemia type 1 . 


\section{Introduction}

Tyrosinemia type 1 (TT1; OMIM276700), also called hepatorenal tyrosinemia, is an inborn error of metabolism, caused by an autosomal recessive inherited deficiency of the enzyme fumarylacetoacetate hydrolase (FAH), which is the last enzyme in the tyrosine catabolic pathway converting fumarylacetoacetate (FAA) into fumarate and acetoacetate. One of the first patients described with TT1 presented with liver cirrhosis, renal tubular defects, and vitamin D-resistant rickets, although the exact diagnosis was not clear at that time [1]. Initially, the primary enzyme defect was considered to be a defect of 4-hydroxyphenylpyruvate dioxygenase (4HPPD) [2,3]. Some years later, it became apparent that the primary enzyme deficiency was located more downstream in the catabolic pathway of tyrosine at FAH (Fig. 1) [4].

The only existing treatment at that time was dietary restriction of tyrosine and its precursor phenylalanine. Unfortunately, when only treated with a phenylalanine/ tyrosine-restricted diet, the outcome was extremely poor. Many TT1 patients did not survive the initial period when presenting with severe liver failure and its associated problems, including ascites and bleeding [5]. If patients survived this period, many died years later due to the development of hepatocellular carcinoma (HCC) or respiratory failure caused by porphyria-like syndrome [5-7]. As a consequence, orthotopic liver transplantation (OLT) was long considered the only definitive option to treat the metabolic as well as the oncological problem [8-10].

This all changed after the introduction of 2-(2-nitro4-trifluoromethylbenzoyl)-1,3-cyclohexanedione (NTBC, also known as nitisinone) as a new treatment option in 1992 [11]. NTBC proved to be a potent inhibitor of the enzyme 4HPPD, which was first thought to be responsible for the disease. In this way, NTBC can prevent the production of the toxic metabolites FAA, maleylacetoacetate, succinylacetoacetate, and succinylacetone (SA), and thereby substantially improves the clinical outcome [12, 13]. However, as a consequence of 4HPPD inhibition by NTBC treatment, tyrosine concentrations increase substantially further, making a phenylalanine/tyrosine-restricted diet again part of the treatment of TT1 [14].

It is now more than 25 years since NTBC was introduced as a treatment option. Since then, many TT1 patients have been treated with NTBC, most of them in combination with the phenylalanine/tyrosine-restricted diet. Many living TT1 patients are diagnosed after presentation with the associated symptoms, although patients are diagnosed increasingly by population-based newborn screening. This review aims to address the outcome of TT1 patients and long-term considerations in the pharmacological treatment of TT1 patients.

\section{NTBC and its Pharmacodynamics and Pharmacokinetics}

Naturally occurring triketones are produced by a number of plants and lichens. They are synthesized to prevent growth of surrounding plants $[15,16]$. NTBC is such a triketone and was one of the first to be used as a herbicide [17]. Experiments revealed that NTBC is a strong inhibitor of the enzyme 4HPPD [18-20], the second enzyme in the catabolic cascade of tyrosine. 4HPPD catalyzes the conversion of 4-hydroxyphenylpyruvate to homogentisate (Fig. 1). Through NTBC-mediated inhibition of the production of homogentisate, the synthesis of tocopherols and plastoquinones in plants is blocked, thereby reducing the production of chlorophyll. In this way, NTBC causes plants to bleach [18]. In humans, it was postulated that NTBC could block further catabolism of tyrosine into its degradation products [11].

The enzyme 4HPPD is a dioxygenase as its reaction utilizes diatomic oxygen for oxidative decarboxylation as well as aromatic ring hydroxylation [21]. NTBC rapidly and tightly binds to the $\mathrm{Fe}$ (II)-containing active site of 4HPPD after a multi-step process. Both NTBC and the substrate 4-hydroxyphenylpyruvate have similar binding interactions, with NTBC especially showing close affinity to the enzyme caused by interactions such as $\pi$-stacking. The binding causes a rapid inactivation of the enzyme by creating an almost irreversible 4HPPD inhibitor complex [20, 22-24]. In vitro experiments with tissue of wild-type rats revealed that a concentration of only $100 \mathrm{nM}$ of NTBC was sufficient to block $>90 \%$ of the enzyme activity, with only a small amount of activity returning after $7 \mathrm{~h}$ [19]. This strong inhibitory reaction was also seen in healthy adult human participants, with a plasma half-life of $54 \mathrm{~h}$ after a single dose of NTBC [25].

In rats, NTBC showed a general tissue distribution pattern shortly after dosing, with NTBC detectable in many different tissues including plasma, eye (cornea and glands), liver, kidneys, lung, and a small amount in the brain [26]. However, retention of NTBC was especially apparent in the liver and kidneys of the investigated wild-type rats and mice [26, 27]. NTBC is excreted in urine and feces, each accountable for about $50 \%$ of the excretion. In urine, NTBC was excreted unchanged, as 4- or 5-hydroxy metabolites, as amino acid conjugate, or as 2-nitro-4-trifluoromethylbenzoic acid after hydrolytic cleavage, while three unidentified metabolites were detected in rat fecal extracts [28-30]. 


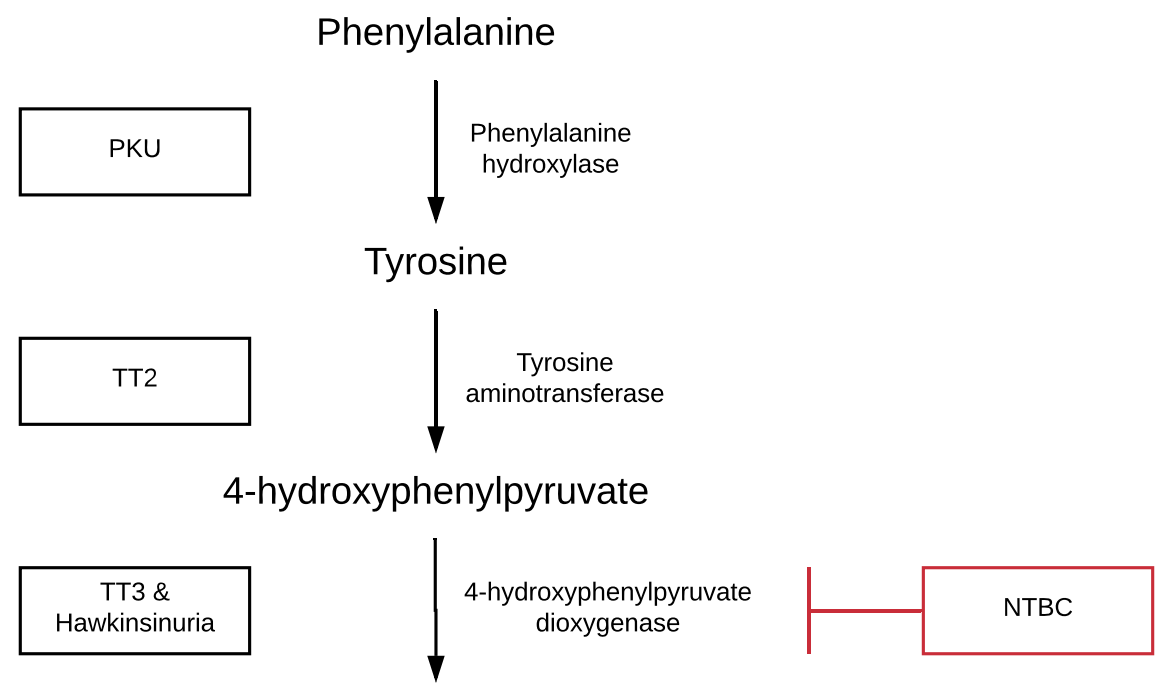

Homogentisic acid

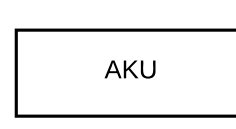

homogentisic acid

dioxygenase

Maleylacetoacetate

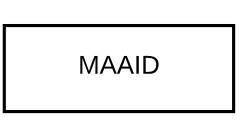

Maleylacetoacetate isomerase or non-enzymatic

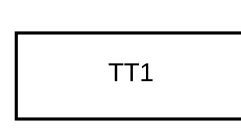

Fumarylacetoacetate $\longrightarrow$ Succinylacetoacetate
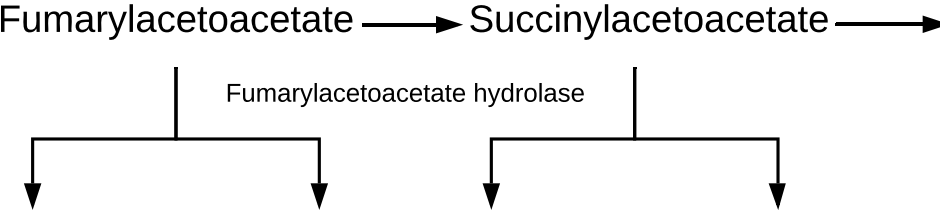

Fumarate

Acetoacetate

Succinate

Fig. 1 Phenylalanine and tyrosine degradation pathway is shown with the different enzymes and corresponding associated metabolic disorders, namely phenylketonuria (PKU), tyrosinemia type 2 (TT2),

\section{Practical Management of NTBC Treatment in Tyrosinemia Type 1 (TT1)}

As NTBC inhibits the enzyme 4HPPD, it was considered to be a potential treatment for TT1 patients by creating a metabolic block upstream from the primary enzymatic defect. Lindstedt et al. [11] were the first to treat TT1 patients with NTBC. The first five patients were treated with NTBC $0.1-0.2 \mathrm{mg} / \mathrm{kg} /$ day, which was gradually increased to $0.4-0.6 \mathrm{mg} / \mathrm{kg} / \mathrm{day}$. Treatment with NTBC led to a tremendous improvement of hallmark biochemical abnormalities, including a decrease in urine and blood SA concentrations, improvement of porphobilinogen synthase activity in erytrocytes and lower urine 5-aminolevulinic acid (5-ALA) tyrosinemia type 3 (TT3), hawkinsinuria, alkaptonuria (AKU), maleylacetoacetate isomerase deficiency (MAAID), and tyrosinemia type 1 (TT1)

concentrations. As a consequence, resulting clinical symptoms such as liver failure and kidney problems improved [11].

Nowadays, the recommendation in Europe, the US, and Canada is to treat patients with $1 \mathrm{mg} / \mathrm{kg} / \mathrm{day}$ [14, 31-33], although there is some advice to start with $2 \mathrm{mg} / \mathrm{kg} /$ day in case of acute liver failure [14], while chronic treatment in stable patients is sometimes given at much lower NTBC doses of around $0.36-0.6 \mathrm{mg} / \mathrm{kg} /$ day [34-36]. Some reports state that NTBC once a day is enough as blood concentrations tend to be stable for at least $24 \mathrm{~h}$ [14, 25, 37, 38], while others favor giving NTBC twice a day to adequately prevent raised bloodspot $\mathrm{SA}$ concentrations [33, 39]. In addition, 
the optimal time for blood sampling is not known and may be dependent on the timing of NTBC administration [39].

Dose optimization of NTBC could be done based on several (indirect) parameters, such as (i) doses individually adjusted to $\mathrm{mg} / \mathrm{kg}$ body weight, (ii) porphobilinogen synthase activity in erythrocytes, (iii) plasma 5-ALA concentrations, (iv) plasma or blood spot NTBC concentrations, or (v) urine, plasma, or blood spot SA concentrations [11, 12]. Unfortunately, recommendations for target blood spot NTBC concentrations are hampered by large inter- and intraindividual variabilities and lack of standardization of NTBC assays [36, 37, 40-44]. Therefore, target blood NTBC concentrations vary mostly between 30 and $60 \mu \mathrm{mol} / \mathrm{L}$, although concentrations ranging between 20 and $150 \mu \mathrm{mol} / \mathrm{L}$ have been reported [14, 32-34, 40, 45, 46]. A detectable or increased SA concentration in blood spots or plasma, or its excretion in urine, is considered to be a sensitive indicator for suboptimal NTBC treatment and reason for adjustment of therapy $[32,33]$. Urine was long considered to be the preferred matrix, mainly because analytical methods were not sensitive enough to analyze the low SA concentrations in plasma or blood spots. However, new techniques have led to a clear improvement in sensitivity [47]. There is currently no consensus on the preferred matrix for monitoring SA. A further increase in the sensitivity of the analytical methods allowed a few laboratories to detect SA in blood spots in healthy individuals, which was previously unnoticed. Therefore, with NTBC treatment, SA concentrations should be targeted to the reference range, but its clinical relevance clearly needs to be established in the coming years $[32,48]$.

To date, there have been only a few reports about adherence to NTBC. One study reported a high level of adherence to the NTBC medication, with only 1 day of reported nonadherence in a 10-week period [49], while others reported adherence problems in about $15 \%$ of the patients [50,51]. Single cases reported that discontinuation of NTBC for 1-8 weeks resulted in severe, life-threatening neurological crises with diaphragm paralysis and respiratory failure [46, 52-56]. However, it is not known whether the use of NTBC was already suboptimal for a longer period of time in these patients. It could be hypothesized that long-term suboptimal use of NTBC is the most important reason for later development of HCC, as has been reported in TT1 mice [57]. Regular measurement of NTBC and SA in blood spots [36, 39, $40,42,47]$ might increase treatment adherence and therapy adjustment accordingly. Further investigation on optimal treatment regimens and cut-off values for biomarkers are therefore essential.

\section{NTBC Treatment in Other Disorders of Tyrosine Metabolism}

As NTBC inhibits the enzyme 4HPPD, it could not only be useful in TT1 but in other disorders of tyrosine metabolism caused by an enzymatic defect downstream from 4HPPD as well. Alkaptonuria (AKU), caused by a deficiency of homogentisate dioxygenase, is one of them (Fig. 1). AKU is characterized by high homogentisic acid concentrations that could result in depositions in connective tissue among others, leading to spondyloarthropathy, cardiac valve disease, stone formation, and osteopenia [58, 59]. A total daily dose of only $2 \mathrm{mg} \mathrm{NTBC}$ already resulted in $95 \%$ reduction of urinary homogentisic acid [60, 61]. Interestingly, this NTBC dose is much lower than the dose given to TT1 patients. This could at least partly be explained as the aim in TT1 is to have no activity of 4HPPD at all, while this is different in AKU. Although this low dose of NTBC initially failed to show a response on non-biochemical outcomes [60], a decrease in clinical progression of eye and ear ochronosis in AKU patients has recently been reported [62, 63]. It is not known whether long-term NTBC treatment in AKU is effective, neither is it known whether NTBC could prevent the severe bone disease caused by ochronosis in AKU patients if started early.

Maleylacetoacetate isomerase deficiency (MAAID) (Fig. 1) has only been found and reported rarely. MAAID is responsible for the conversion of maleylacetoacetate to FAA and is characterized by relatively mildly increased plasma and urine SA concentrations and a normal amino acid profile [64]. The first reported patient with proven MAAID had severe liver and renal failure. However, a favorable outcome without any liver or renal disease has recently been described in six untreated MAAID patients [64]. This is in agreement with the MAAID knockout mice that under normal circumstances did not show a clinical phenotype, although liver and renal damage could be induced by a phenylalanine-enriched diet [65]. Thus, it can't be excluded that MAAID patients under certain circumstances could show liver and renal problems. However, for now there seems no need for NTBC in the regular treatment of MAAID.

Another rarely reported disease of tyrosine metabolism is hawkinsinuria. Hawkinsinuria is not caused by a defect downstream of 4HPPD like the previously mentioned diseases, but is supposed to be caused by an autosomal dominant mutation in the 4HPPD enzyme itself [66-68]. Next to hypertyrosinemia, this mutation causes the formation of hawkinsin instead of homogentisate [68]. It is not certain whether this defect always results in clear clinical manifestations, although transient metabolic acidosis during infancy with vomiting and diarrhea and consequently failure to thrive have been reported [69-73]. In rats, NTBC has shown 
to inhibit the mutant 4HPPD enzyme in a similar way as the normal 4HPPD enzyme, indicating a possible treatment strategy for symptomatic infants with hawkinsinuria [68].

Apart from 4HPPD defects or defects downstream of 4HPPD, phenylketonuria (PKU) could also be reasoned to benefit from NTBC treatment [74]. Due to the competitive effect on the blood-brain barrier, high plasma phenylalanine concentrations could, among others, lead to low brain tyrosine concentrations [75]. When increasing plasma tyrosine concentrations by NTBC, it could be reasoned that plasma phenylalanine:tyrosine ratios and consequently brain phenylalanine, tyrosine, and dopamine concentrations improve. This in turn might improve the neurocognitive outcome [76-79]. Data from Harding et al. indeed showed that treatment with NTBC in PKU mice led to a clear decrease in brain phenylalanine and increase in tyrosine and dopamine concentrations and could thus be an adjunct therapy in PKU [74].

\section{Adverse Effects of NTBC}

NTBC seems to be well tolerated with only a few reported adverse effects. One of the main concerns about the treatment with NTBC are the eye problems associated with it. Most of the rats treated with NTBC soon developed corneal opacities [26]. The similarity between the corneal problems in NTBC-treated rats and rats fed with a tyrosine-enriched diet led to the conclusion that the corneal lesions are caused by the poor solubility of tyrosine and are thus secondary to the increase in tyrosine concentrations induced by NTBC rather than a toxic effect of NTBC itself $[26,80]$. However, this could not be the only explanation as clear interspecies differences in ocular problems are found [27, 28, 81].

Due to the associated increase in tyrosine concentrations and secondary development of ocular problems, NTBC treatment has from the start been combined with a phenylalanine/tyrosine-restricted diet [11]. Currently, treatment recommendations vary between different centers and countries, with upper tyrosine concentrations varying between 400 and $600 \mu \mathrm{mol} / \mathrm{L}$ [14, 31-33, 82, 83], although higher levels up to $800 \mu \mathrm{mol} / \mathrm{L}$ are sometimes accepted in practice [45]. Despite the dietary restriction, eye problems are still found in approximately $5-10 \%$ of the TT1 patients [12, 31]. The most frequently reported eye problems are transient itching, burning, and photophobia [12, 31, 51], although silent keratopathy, clinical corneal opacities, or even corneal crystals presenting as pseudodendritic lesions have been reported [12, 46, 63, 84-87]. Although no clear correlation between ocular problems and tyrosine concentrations could be found, withdrawal of NTBC or stricter adherence to the phenylalanine/tyrosine-restricted diet resolves the corneal lesions $[12,13,87]$. Therefore, ophthalmic follow-up is necessary and in case of eye problems, specific eye investigations with a slit lamp should be considered, while the diet should be intensified [82, 88].

In addition to high tyrosine concentrations caused by NTBC treatment, phenylalanine concentrations below the lower limit of normal are often found in TT1 patients [11, 13, 89-92]. Although these low phenylalanine concentrations are usually expected to be caused by the phenylalanine/ tyrosine-restricted diet, NTBC itself seems to lower plasma phenylalanine concentrations as well [74]. The mechanism by which NTBC treatment lowers plasma phenylalanine is not understood. Low phenylalanine concentrations have been associated with growth retardation, neurological impairments, and skin problems in an infant with TT1 [91]. Therefore, phenylalanine supplementation has been suggested to prevent these low phenylalanine concentrations, although the exact dosage and its effect on phenylalanine concentrations is not clear yet [33, 89, 91, 93]. No uniform consensus guidelines exist, but the usual advice is to keep phenylalanine concentrations within the normal range $(38-78 \mu \mathrm{mol} / \mathrm{L})$ $[32,94]$. Because of the expected drop in phenylalanine concentrations in the afternoon, we advised to keep fasting phenylalanine concentrations above $50 \mu \mathrm{mol} / \mathrm{L}$ [92].

Other reported adverse effects of NTBC are relatively uncommon, minor, and/or transient and usually do not require disruption of NTBC treatment. The most frequently reported adverse effects (except for ocular problems) are leukopenia, thrombocytopenia, or granulocytopenia (all $<10 \%)$, and pruritus, exfoliative dermatitis, erythematous rash, myoclonia, or constipation (all <1\%) [12, 14, 45, 46, 50, 63, 95].

\section{Outcome in TT1 Before and After Introduction of NTBC}

\subsection{Liver Problems}

Especially FAA, but maybe also maleylacetoacetate, has been shown to be cytotoxic and mutagenic and causes glutathione depletion, oxidative stress, chromosomal instability, cell cycle arrest, and apoptosis in the cells where it is generated, primarily hepatocytes [96-99]. As a consequence, TT1 is characterized by progressive liver disease, and could be classified into different categories based on their moment of presentation, associated symptomatology, and resulting outcome [5]. The majority of the patients presented (very) early with severe acute liver failure and associated pronounced coagulopathy, ascites (with or without spontaneous bacterial peritonitis) due to low albumin concentrations, and hypoglycemia. In particular, these early presenting patients had a poor outcome, with only $10-30 \%$ of the patients still alive 2 years after diagnosis $[5,100]$. In later presenting patients, liver problems are usually less pronounced, although HCC 
could be present already [5, 101-105]. When patients survived the initial period, there was a high risk for developing chronic liver disease, cirrhosis, and eventually HCC when treated with a phenylalanine/tyrosine-restricted diet only [5, $6,104]$. Therefore, OLT was long considered the only definitive option to prevent metabolic and oncological problems [8-10, 103, 106-110].

The introduction of NTBC results in a quick recovery of liver function, although about $10 \%$ of the patients with (acute) liver failure do not respond to the treatment [12, 31, $50,83,111]$. In most patients, the coagulopathy quickly resolves, porphobilinogen synthase activity reaches normal levels within a month, 5-ALA excretion in urine normalizes in most cases, and urinary and blood SA concentrations normalize completely after some days or months, respectively $[11,31,83,112]$. Alfa-fetoprotein (AFP), the biochemical marker for HCC in TT1, decreased slowly over some months to normal values. The risk of liver cancer (mainly HCC, although hepatoblastoma could occur) decreased tremendously and is estimated to be around $1 \%$ if NTBC treatment is initiated early $[11,13,31,83,113]$. In line with this, longterm follow-up revealed that NTBC-treated TT1 patients are still at risk for HCC, especially when NTBC is initiated late due to delayed diagnosis or unavailability of NTBC $[13,31$, $46,55,114-121]$.

So far, no HCC development in pre-clinically treated patients has been reported [13, 120, 122-124]. However, HCC is still seen in TT1 mice, even if NTBC is started prenatally and high amounts are given after birth in combination with a phenylalanine/tyrosine-restricted diet [125, 126]. In addition, gene expression patterns and collagen metabolism are also not fully normalized in TT1 patients receiving NTBC $[127,128]$. Due to this increased risk to develop HCC, screening is still recommended using regular AFP measurements and imaging such as ultrasound and magnetic resonance imaging (MRI) in case of a suspect lesion [14, 32, 45, 82, 123, 124]. In contrast to other diseases with a high risk of developing HCC (e.g., hepatitis B and C), AFP has always been considered a reliable marker for liver cancer in TT1 [14, 113, 115]. However, HCC may develop without clear rise in AFP and additional markers are currently being investigated [118, 124, 129]. Thus, at present, both a lesion at imaging and a rise in AFP should be considered pathognomonic for $\mathrm{HCC}$, while a slow decrease of AFP, or an AFP level that remains above the upper limit of normal after 2 years of age are predictive signs of HCC development and should be discussed with the OLT team as well $[115,118]$.

\subsection{Renal Problems}

FAA not only affects hepatocytes, but tubular cells of the kidney as well. FAA can cause oxidative stress, acute apoptosis, and cellular death in proximal tubular cells just as in hepatocytes [130]. In addition, SA has been shown to reduce sugar and amino acid uptake in the proximal tubulus leading to renal Fanconi syndrome [130, 131]. In contrast to liver failure, these renal tubular problems are apparent as well in late-presenting TT1 patients [45]. The characteristic renal disease in TT1 patients is a renal tubulopathy with aminoaciduria, glucosuria, phosphaturia, and acidosis (that is difficult to fully correct) and, as a consequence, secondary hypophosphatemic (vitamin D-resistant) rickets may develop. However, the severity of the renal problems varies significantly between patients $[45,50,55,132]$. Dietary restriction of phenylalanine and tyrosine and supplementation of minerals and vitamins seem to improve renal tubular defects (even without NTBC) in some patients. In dietary-treated patients, this partial response together with non-adherence may result in progression to nephromegaly, nephrocalcinosis, glomerulosclerosis, or even renal failure [133-138].

Administration of NTBC in patients with renal tubular dysfunction results in an improvement in kidney function with normalization of phosphate reabsorption and plasma phosphate concentrations, usually within a month $[11,136$, 139], although sometimes less rapidly than for the liver problems. A slower but continuous improvement could be seen in other parameters such as glucosuria, proteinuria, excretion of macroglobulin, plasma uric acid, plasma calcium, and rickets within the following years; mineral and vitamin supplements could usually be withdrawn [111, 132, 136, 139, 140]. Long-term follow-up of adequately NTBCtreated patients revealed a normal tubular function in most of the patients [34, 132, 138], although minor tubulopathy without clinical consequences and already existing nephrocalcinosis may persist $[46,50,51,132,136]$. In pre-clinically diagnosed patients, none of the patients showed clinically significant renal problems at diagnosis or developed renal problems while on NTBC [13, 122]. Annual clinical followup with laboratory evaluation and renal ultrasound is recommended for TT1 patients $[32,45]$.

\subsection{Neurological Problems}

Recurrent neurological crises could be present in up to $40 \%$ of the TT1 patients treated by diet alone and were a main cause of hospitalization or even mortality $[5,7]$. The neurological crises were usually provoked by a minor infection and presented as a peripheral neuropathy with hypertonia, paralytic ileus with vomiting, or muscle weakness that could progress to paralysis or even respiratory failure that could mimic the progressive weakness in Guillain-Barre syndrome [7, 141].

Treatment with NTBC results in a rapid decline in SA, resulting in an increase in porphobilinogen synthase activity 
and, as a consequence, normalization of 5-ALA concentrations that were thought to be responsible for the neurological crises or so-called porphyria-like-syndrome [7, 11]. As a result, the neurological symptoms have completely disappeared after the start of NTBC treatment [13, 31, 50, 141]. However, when NTBC treatment is interrupted, severe neurological crises may reappear, mimicking the porphyria-likesyndrome described above.

\subsection{Neuropsychological Problems}

No consistent cognitive or behavioral deficiencies were reported in TT1 patients prior to the introduction of NTBC. In contrast, intellectual development and school performance was considered to be normal, even in patients with recurrent neurological crises. However, in more recent years, after the introduction of NTBC, several studies reported a non-optimal cognitive development in TT1 patients. In 2008, 35\% of French TT1 patients retrospectively showed school problems [50]. Later research showed a broad range of neurocognitive problems, especially in children with TT1. These neurocognitive problems include a lower (performance and verbal) IQ [46, 119, 142-144] and even regression of IQ over time [145, 146], abnormal motor skills [143, 147], impaired executive functioning (including affected working memory and cognitive flexibility), and non-optimal social cognition $[144,147]$ and behavioral problems such as attention deficits [148]. Next to these neurocognitive problems, structural changes in the brain are found in some TT1 patients. MRI of two TT1 patients showed white matter problems and myelination deficits $[149,150]$ and positron emission tomography/computed tomography scans showed abnormal bilateral hypometabolism in one out of three adult patients [147]. However, this is contradicted by the study of Thimm et al. that showed no MRI abnormalities [143]. Various hypotheses have been suggested to explain these neurocognitive disturbances: (i) the disease itself, with toxic products and associated liver failure [151, 152], (ii) treatment with NTBC, (iii) high plasma tyrosine concentrations either being toxic in itself or changing neurotransmitter metabolism, (iv) high plasma tyrosine concentrations that compete with the uptake of other amino acids and thus impair cerebral protein synthesis in general or impair neurotransmitter synthesis caused by decreased brain influx of tryptophan, or (v) low plasma and corresponding brain phenylalanine concentrations [141]. To test these different hypotheses, associations between the neurocognitive deficiencies and alterations of blood TT1 phenylalanine or tyrosine concentrations have been sought. So far, no specific group of TT1 patients at risk for neurocognitive deficiencies could be identified, as non-optimal neurocognitive outcomes have been seen in pre-clinically diagnosed, clinically diagnosed, and transplanted patients [144, 153]. Also, a correlation between low blood phenylalanine or low phenylalanine/tyrosine ratio and neurocognitive outcome was found only in two studies $[142,146]$. To investigate this further, Thimm et al. measured increased tyrosine concentrations in cerebral spinal fluid while 5-HIAA concentrations were decreased, possibly indicating central nervous system serotonin deficiency, but no direct measurement of brain serotonin has been made in TT1 [154].

During clinical follow-up, psychomotor and intelligence testing is rarely routinely performed [45], although it has been advised to perform neuropsychological testing before school age and at regular intervals afterwards [14, 32].

\subsection{Other Symptoms}

Hypertrophic obstructive cardiomyopathy has been a rarely reported symptom in TT1 patients treated with a phenylalanine/tyrosine-restricted diet [104, 155, 156], which reportedly resolves completely within some months after start of NTBC treatment [157-159]. Other rare reported accompanying symptoms at diagnosis include transient carnitine deficient myopathy, likely caused by renal Fanconi tubulopathy [160], and transient hyperinsulinism with hypertrophy of the islets of Langerhans [100, 161]. To date, there have been no reports of adverse cardiac symptoms while taking NTBC [158], nor about any other of the rarely reported complications mentioned above.

\section{Future Considerations and Remaining Challenges for TT1}

\subsection{Pregnancy}

With the tremendously improved clinical outcome and survival probability, pregnancy in TT1-affected mothers treated with NTBC have been reported [162-164]. Not much is known about a possible teratogenic effect of NTBC. However, very high dosages of NTBC have been associated with corneal lesions, malformations, and reduced survival in offspring of NTBC-treated laboratory animals [162], while prenatally prescribed normal dosages do prevent early death in TT1 mice and pigs without any teratogenicity [57, 165].

In human pregnancies, NTBC has been continued in all three reported cases. Two unaffected children had a normal birth weight, while the birth weight of one child with TT1 was in the low normal range. All three infants were healthy without signs of malformations and had normal development later on while receiving between 0.5 and $1.0 \mathrm{mg} / \mathrm{kg}$ NTBC during pregnancy with maternal tyrosine concentrations up to $700-800 \mu \mathrm{mol} / \mathrm{L}$ [162-164]. After delivery, neonatal blood NTBC concentrations reduced slowly while receiving bottle feeding [163, 164], until SA became detectable in urine and AFP concentrations rose slightly after an 
initial decline 2 weeks after birth in the TT1-affected child [162]. All reported TT1 mothers were healthy with no sign of liver, renal or neurological deterioration during pregnancy [162-164].

Although no clear guidelines exist and existing data is limited, current knowledge suggests that NTBC treatment in pregnant TT1 patients should be continued with strict monitoring considering the possible complications for the pregnant TT1 patient associated with an interruption in NTBC treatment [48].

\subsection{Long-Term Follow-Up}

With the introduction of NTBC, the outcome of TT1 patients improved considerably as explained above. As about $10 \%$ of the patients presenting with liver failure do not respond early enough to NTBC to prevent OLT, and the risk of HCC is still clearly elevated when NTBC treatment is started late, a further improvement reduction in liver-related morbidity is expected with the universal introduction of neonatal screening $[13,122]$. With early introduction of NTBC, important clinical symptomatology can be prevented, although the very long-term effects of NTBC, both in terms of effectiveness and toxicity, remain to be evaluated. At this time, it is clear that strict follow-up for possible HCC is still needed as it is not certain whether NTBC only delays the development of $\mathrm{HCC}$ or completely prevents $\mathrm{HCC}$ formation when started after pre-clinical neonatal diagnosis. However, in light of the uncertain long-term effectiveness and potential new toxicities, strict monitoring of the disease is of crucial importance. This is hampered by the fact that no clear guidelines on effective dosing and safe concentrations of NTBC and safe concentrations of biochemical parameters such as blood or urine SA, and blood tyrosine and phenylalanine concentrations currently exist. Therefore, neurocognitive, psychosocial, ophthalmic, physical, and nutritional followup is necessary to prevent complications of high tyrosine concentrations and to assess vitamin and mineral status. Furthermore, continued research is necessary to address the neurocognitive functioning, its relationship with current treatment strategies, and to reveal the pathophysiological mechanisms causing the brain impairments.

\subsection{Considerations from a Cost Perspective}

NTBC is one of the 20 most expensive drugs [166], with reported annual costs between US $\$ 70,000$ and US $\$ 140,000$ for a person of $50 \mathrm{~kg}$ depending on manufacturer and country of issue $[167,168]$. Despite this, only one cost-effectiveness study has been performed [169]. As a consequence of the improved clinical outcome, NTBC lowered the utilization of health care and associated costs for hospital visits and admissions, although total yearly costs increased significantly with NTBC treatment [169].

Developing drugs for rare diseases, the so-called orphan drugs (affecting $<1: 2000$ individuals according to criteria in the EU) has been-and still is - an unmet need in many of those rare and ultra-rare diseases. However, with the adoption of Regulation (EC) No. 141/2000 in the EU, many new orphan drugs are coming to market every year as a result of intensifying rare disease research and drug development. Incentives for companies, including fee reductions and, importantly, 10-year market exclusivity, has stimulated this development. In combination with an emphasis on personalized medicine as a consequence of advances in (genetic) technology, the drug market is switching towards development of orphan medicines.

Although patients, families, and healthcare professionals welcome more treatment options, this increasing 'orphanization' of the healthcare system has fueled concerns among regulatory bodies, payers, healthcare professionals, and patients because of the high prices. A major concern in this respect is the observation that some orphan medicines reach the market in an immature stage: while pivotal trials show promising results, insufficient knowledge of long-term, clinically relevant outcomes and the price in itself withholds reimbursement, which leads to unequal access to orphan drugs [170]. Hence, new pharmaceutical developmental models need to be developed, including better and more independent evaluation of outcomes, for example in adaptive pathway models [171] as well as reimbursement models, taking cost effectiveness, uncertainty, and development costs into consideration. With regard to NTBC, all of the above applies; uncertainty of long-term effectiveness and toxicity requires improved, collaborative monitoring, with open data sharing and independent outcome analysis. This is important to support healthcare professionals to make rational choices for treatment for the benefit of their patients: at this time, partly because of costs, some centers advocated to perform OLT instead of the conservative treatment with NTBC and a combined phenylalanine/tyrosine-restricted diet.

\subsection{Possible New Strategies}

So far, no HCC has been reported in pre-clinically diagnosed TT1 patients. However, as FAH is expressed in utero and AFP concentrations are raised at birth, a prenatal start to liver disease is likely $[57,172,173]$. Therefore, prenatal diagnosis and prevention of prenatal liver disease could theoretically be achieved with the prescription of NTBC to unaffected mothers. Alternatively, recent advances have shown in utero gene editing to abolish neonatal lethal liver disease in TT1 mice [174]. As TT1 mice still develop HCC even if $90-95 \%$ of the liver cells are corrected, long-term efficacy of cell or gene therapy was thought to require all 
liver cells to be targeted to prevent HCC formation in original FAH deficient cells [125, 175]. However, liver-directed gene therapy in a TT1 pig has been shown to be effective without signs of liver fibrosis or HCC development after 3 years of follow-up and could thus be a potential alternative therapeutic approach that needs to be explored [176].

\section{Conclusion}

This review showed that NTBC has clearly improved the treatment and outcomes for patients with TT1. During the last 25 years, NTBC treatment has proved to be generally safe, well tolerated, and effective. Where OLT was once considered the only definitive option, OLT is now only used in cases that fail to respond to NTBC and when liver cancer develops. To further reduce the risk of long-term complications such as HCC and neurocognitive issues, and to prevent clinical symptoms, pre-clinical diagnosis with blood spot SA measurements in newborn screening is necessary. The exact risks for the development of complications associated with the disease, NTBC, and long-term dietary treatment are not known yet and therefore strict follow-up is necessary. Future challenges will be to develop uniform guidelines for treatment and follow-up, reliable detection of possible liver cancer, and weighing the risks, challenges, and costs of existing and alternative strategies for the treatment of TT1.

\section{Compliance with ethical standards}

Funding No external funding was secured for this study.

Conflict of interest ILR has received research grants from SOBI. CEMH is involved in pre-marketing studies with Sanofi, Protalix, and Idorsia in the field of lysosomal storage disorders. She is advisor for drug regulatory agencies and a member of the Advisory Committee to the insurance package of the National Heath Care Institute. FJvS has received research grants, advisory board fees, and speakers honoraria from Nutricia Research, Merck-Serono, Biomarin, Codexis, Alexion, Vitaflo, MendeliKABS, Promethera, SOBI, APR, ARLA Foods Int., Eurocept, Lucane, nestle-Codexis Alliance, Orphan Europe, Rivium Medical BV, Origin, Agios, NPKUA, ESPKU, NPKUV, Tyrosinemia Foundation and Pluvia Biotech. WGvG, $\mathrm{COH}$ and MRHF have indicated that they have no potential conflicts of interest to disclose.

Open Access This article is distributed under the terms of the Creative Commons Attribution-NonCommercial 4.0 International License (http://creativecommons.org/licenses/by-nc/4.0/), which permits any noncommercial use, distribution, and reproduction in any medium, provided you give appropriate credit to the original author(s) and the source, provide a link to the Creative Commons license, and indicate if changes were made.

\section{References}

1. Baber MD. A case of congenital cirrhosis of the liver with renal tubular defects akin to those in the Fanconi syndrome. Arch Dis Child. 1956;31:335-9.

2. Gentz J, Jagenburg R, Zetterstroem R. Tyrosinemia. J Pediatr. $1965 ; 66: 670-96$.

3. Kitagawa T. Hepatorenal tyrosinemia. Proc Jpn Acad Ser B Phys Biol Sci. 2012;88:192-200.

4. Lindblad B, Lindstedt S, Steen G. On the enzymic defects in hereditary tyrosinemia. Proc Natl Acad Sci USA. 1977;74:4641-5.

5. van Spronsen FJ, Thomasse Y, Smit GP, Leonard JV, Clayton PT, Fidler V, Berger R, Heymans HS. Hereditary tyrosinemia type I: a new clinical classification with difference in prognosis on dietary treatment. Hepatology. 1994;20:1187-91.

6. Weinberg AG, Mize CE, Worthen HG. The occurrence of hepatoma in the chronic form of hereditary tyrosinemia. J Pediatr. 1976;88:434-8.

7. Mitchell G, Larochelle J, Lambert M, Michaud J, Grenier A, Ogier H, Gauthier M, Lacroix J, Vanasse M, Larbrisseau A. Neurologic crises in hereditary tyrosinemia. N Engl J Med. 1990;322:432-7.

8. van Spronsen FJ, Berger R, Smit GP, de Klerk JB, Duran M, Bijleveld CM, van Faassen H, Slooff MJ, Heymans HS. Tyrosinaemia type I: orthotopic liver transplantation as the only definitive answer to a metabolic as well as an oncological problem. J Inherit Metab Dis. 1989;12(Suppl 2):339-42.

9. Wijburg FA, Reitsma WC, Slooff MJ, van Spronsen FJ, Koetse HA, Reijngoud DJ, Smit GP, Berger R, Bijleveld CM. Liver transplantation in tyrosinaemia type I: the Groningen experience. J Inherit Metab Dis. 1995; 18:115-8.

10. van Spronsen FJ, Smit GP, Wijburg FA, Thomasse Y, Visser G, Heymans HS. Tyrosinaemia type I: considerations of treatment strategy and experiences with risk assessment, diet and transplantation. J Inherit Metab Dis. 1995;18:111-4.

11. Lindstedt S, Holme E, Lock EA, Hjalmarson O, Strandvik B. Treatment of hereditary tyrosinaemia type I by inhibition of 4-hydroxyphenylpyruvate dioxygenase. Lancet. 1992;340:813-7.

12. Holme E, Lindstedt S. Tyrosinaemia type I and NTBC (2-(2-nitro-4-trifluoromethylbenzoyl)-1,3-cyclohexanedione). J Inherit Metab Dis. 1998;21:507-17.

13. Larochelle J, Alvarez F, Bussieres JF, Chevalier I, Dallaire L, Dubois J, Faucher F, Fenyves D, Goodyer P, Grenier A, Holme E, Laframboise R, Lambert M, Lindstedt S, Maranda B, Melancon S, Merouani A, Mitchell J, Parizeault G, Pelletier L, Phan V, Rinaldo P, Scott CR, Scriver C, Mitchell GA. Effect of nitisinone (NTBC) treatment on the clinical course of hepatorenal tyrosinemia in Quebec. Mol Genet Metab. 2012;107:49-54.

14. de Laet C, Dionisi-Vici C, Leonard JV, McKiernan P, Mitchell G, Monti L, de Baulny HO, Pintos-Morell G, Spiekerkotter U. Recommendations for the management of tyrosinaemia type 1 . Orphanet J Rare Dis. 2013;8:8.

15. van Klink JW, Brophy JJ, Perry NB, Weavers RT. Beta-triketones from myrtaceae: isoleptospermone from leptospermum scoparium and papuanone from corymbia dallachiana. J Nat Prod. 1999;62:487-9.

16. Romagni JG, Meazza G, Nanayakkara NP, Dayan FE. The phytotoxic lichen metabolite, usnic acid, is a potent inhibitor of plant p-hydroxyphenylpyruvate dioxygenase. FEBS Lett. 2000;480:301-5.

17. Michaely WJ, Kraatz GW. Certain 2-(substituted benzoyl)1,3-cyclohexanediones and their use as herbicides US06/880,370. 1988. 
18. Schulz A, Ort O, Beyer P, Kleinig H. SC-0051, a 2-benzoylcyclohexane-1,3-dione bleaching herbicide, is a potent inhibitor of the enzyme p-hydroxyphenylpyruvate dioxygenase. FEBS Lett. 1993;318:162-6.

19. Ellis MK, Whitfield AC, Gowans LA, Auton TR, Provan WM, Lock EA, Smith LL. Inhibition of 4-hydroxyphenylpyruvate dioxygenase by 2-(2-nitro-4-trifluoromethylbenzoyl)-cyclohexane-1,3-dione and 2-(2-chloro-4-methanesulfonylbenzoyl)cyclohexane-1,3-dione. Toxicol Appl Pharmacol. 1995;133:12-9.

20. Kavana M, Moran GR. Interaction of (4-hydroxyphenyl) pyruvate dioxygenase with the specific inhibitor 2-[2-nitro-4(trifluoromethyl)benzoyl]-1,3-cyclohexanedione. Biochemistry. 2003;42:10238-45.

21. Moran GR. 4-Hydroxyphenylpyruvate dioxygenase. Arch Biochem Biophys. 2005;433:117-28.

22. Brownlee JM, Johnson-Winters K, Harrison DH, Moran GR. Structure of the ferrous form of (4-hydroxyphenyl)pyruvate dioxygenase from Streptomyces avermitilis in complex with the therapeutic herbicide. NTBC Biochem. 2004;43:6370-7.

23. Neidig ML, Decker A, Kavana M, Moran GR, Solomon EI. Spectroscopic and computational studies of NTBC bound to the non-heme iron enzyme (4-hydroxyphenyl)pyruvate dioxygenase: active site contributions to drug inhibition. Biochem Biophys Res Commun. 2005;338:206-14.

24. Molchanov S, Gryff-Keller A. Inhibition of 4-hydroxyphenylpyruvate dioxygenase by 2-[2-nitro-4-(trifluoromethyl) benzoyl]-1,3-cyclohexanedione. Acta Biochim Pol. 2009;56:447-54.

25. Hall MG, Wilks MF, Provan WM, Eksborg S, Lumholtz B. Pharmacokinetics and pharmacodynamics of NTBC (2-(2-nitro4-fluoromethylbenzoyl)-1,3-cyclohexanedione) and mesotrione, inhibitors of 4-hydroxyphenyl pyruvate dioxygenase (HPPD) following a single dose to healthy male volunteers. Br J Clin Pharmacol. 2001;52:169-77.

26. Lock EA, Gaskin P, Ellis MK, Provan WM, Robinson M, Smith LL, Prisbylla MP, Mutter LC. Tissue distribution of 2-(2-nitro4-trifluoromethylbenzoyl)cyclohexane-1-3-dione (NTBC): effect on enzymes involved in tyrosine catabolism and relevance to ocular toxicity in the rat. Toxicol Appl Pharmacol. 1996;141:439-47.

27. Lock EA, Gaskin P, Ellis MK, McLean Provan W, Robinson M, Smith LL. Tissue distribution of 2-(2-nitro4-trifluoromethylbenzoyl)-cyclohexane-1,3-dione (NTBC) and its effect on enzymes involved in tyrosine catabolism in the mouse. Toxicology. 2000;144:179-87.

28. Lock EA, Ellis MK, Gaskin P, Robinson M, Auton TR, Provan WM, Smith LL, Prisbylla MP, Mutter LC, Lee DL. From toxicological problem to therapeutic use: the discovery of the mode of action of 2-(2-nitro-4-trifluoromethylbenzoyl)-1,3-cyclohexanedione (NTBC), its toxicology and development as a drug. J Inherit Metab Dis. 1998;21:498-506.

29. Szczecinski P, Lamparska D, Gryff-Keller A, Gradowska W. Identification of 2-[2-nitro-4-(trifluoromethyl)benzoyl]cyclohexane-1,3-dione metabolites in urine of patients suffering from tyrosinemia type I with the use of $1 \mathrm{H}$ and 19F NMR spectroscopy. Acta Biochim Pol. 2008;55:749-52.

30. Herebian D, Lamshoft M, Mayatepek E, Spiekerkoetter U. Identification of NTBC metabolites in urine from patients with hereditary tyrosinemia type 1 using two different mass spectrometric platforms: triple stage quadrupole and LTQ-Orbitrap. Rapid Commun Mass Spectrom. 2010;24:791-800.

31. Holme E, Lindstedt S. Nontransplant treatment of tyrosinemia. Clin Liver Dis. 2000;4:805-14.

32. Chinsky JM, Singh R, Ficicioglu C, van Karnebeek CDM, Grompe M, Mitchell G, Waisbren SE, Gucsavas-Calikoglu M, Wasserstein MP, Coakley K, Scott CR. Diagnosis and treatment of tyrosinemia type I: a US and Canadian consensus group review and recommendations. Genet Med. 2017. https://doi. org/10.1038/gim.2017.101 (Epub 2017 Aug 3).

33. Quebec NTBC Study Group, Alvarez F, Atkinson S, Bouchard M, Brunel-Guitton C, Buhas D, Bussieres JF, Dubois J, Fenyves D, Goodyer P, Gosselin M, Halac U, Labbe P, Laframboise R, Maranda B, Melancon S, Merouani A, Mitchell GA, Mitchell J, Parizeault G, Pelletier L, Phan V, Turcotte JF. The Quebec NTBC Study. Adv Exp Med Biol. 2017;959:187-95.

34. El-Karaksy H, Rashed M, El-Sayed R, El-Raziky M, El-Koofy N, El-Hawary M, Al-Dirbashi O. Clinical practice. NTBC therapy for tyrosinemia type 1: how much is enough? Eur J Pediatr. 2010;169:689-93.

35. D'Eufemia P, Celli M, Tetti M, Finocchiaro R. Tyrosinemia type I: long-term outcome in a patient treated with doses of NTBC lower than recommended. Eur J Pediatr. 2011;170:4 (Epub 2011 Feb 22).

36. Sander J, Janzen N, Terhardt M, Sander S, Gokcay G, Demirkol M, Ozer I, Peter M, Das AM. Monitoring tyrosinaemia type I: blood spot test for nitisinone (NTBC). Clin Chim Acta. 2011;412:134-8.

37. Schlune A, Thimm E, Herebian D, Spiekerkoetter U. Single dose NTBC-treatment of hereditary tyrosinemia type I. J Inherit Metab Dis. 2012;35:831-6.

38. Guffon N, Broijersen A, Palmgren I, Rudebeck M, Olsson B. Open-label single-sequence crossover study evaluating pharmacokinetics, efficacy, and safety of once-daily dosing of nitisinone in patients with hereditary tyrosinemia type 1. JIMD Rep. 2018;38:81-8.

39. Kienstra NS, van Reemst HE, van Ginkel WG, Daly A, van Dam E, MacDonald A, Burgerhof JGM, de Blaauw P, McKiernan PJ, Heiner-Fokkema MR, van Spronsen FJ. Daily variation of NTBC and its relation to succinylacetone in tyrosinemia type 1 patients comparing a single dose to two doses a day. J Inherit Metab Dis. 2018;41:181-6.

40. Herebian D, Spiekerkotter U, Lamshoft M, Thimm E, Laryea M, Mayatepek E. Liquid chromatography tandem mass spectrometry method for the quantitation of NTBC (2-(nitro4-trifluoromethylbenzoyl)1,3-cyclohexanedione) in plasma of tyrosinemia type 1 patients. J Chromatogr B Analyt Technol Biomed Life Sci. 2009;877:1453-9.

41. Cansever MS, Aktuglu-Zeybek AC, Erim FB. Determination of NTBC in serum samples from patients with hereditary tyrosinemia type I by capillary electrophoresis. Talanta. 2010;80:1846-8.

42. Prieto JA, Andrade F, Lage S, Aldamiz-Echevarria L. Comparison of plasma and dry blood spots as samples for the determination of nitisinone (NTBC) by high-performance liquid chromatography-tandem mass spectrometry. Study of the stability of the samples at different temperatures. J Chromatogr B Analyt Technol Biomed Life Sci. 2011;879:671-6.

43. la Marca G, Malvagia S, Materazzi S, Della Bona ML, Boenzi S, Martinelli D, Dionisi-Vici C. LC-MS/MS method for simultaneous determination on a dried blood spot of multiple analytes relevant for treatment monitoring in patients with tyrosinemia type I. Anal Chem. 2012;84:1184-8.

44. Davit-Spraul A, Romdhane H, Poggi-Bach J. Simple and fast quantification of nitisone (NTBC) using liquid chromatographytandem mass spectrometry method in plasma of tyrosinemia type 1 patients. J Chromatogr Sci. 2012;50:446-9.

45. Mayorandan S, Meyer U, Gokcay G, Segarra NG, de Baulny HO, van Spronsen F, Zeman J, de Laet C, Spiekerkoetter U, Thimm E, Maiorana A, Dionisi-Vici C, Moeslinger D, BrunnerKrainz M, Lotz-Havla AS, Cocho de Juan JA, Couce Pico ML, Santer R, Scholl-Burgi S, Mandel H, Bliksrud YT, Freisinger P, Aldamiz-Echevarria LJ, Hochuli M, Gautschi M, Endig J, Jordan J, McKiernan P, Ernst S, Morlot S, Vogel A, Sander J, Das AM. 
Cross-sectional study of 168 patients with hepatorenal tyrosinaemia and implications for clinical practice. Orphanet J Rare Dis. 2014;9:7.

46. Zeybek AC, Kiykim E, Soyucen E, Cansever S, Altay S, Zubarioglu T, Erkan T, Aydin A. Hereditary tyrosinemia type 1 in Turkey: twenty year single-center experience. Pediatr Int. 2015;57:281-9.

47. Johnson DW, Gerace R, Ranieri E, Trinh MU, Fingerhut R. Analysis of succinylacetone, as a Girard T derivative, in urine and dried bloodspots by flow injection electrospray ionization tandem mass spectrometry. Rapid Commun Mass Spectrom. 2007;21:59-63.

48. Mitchell GA, Yang H. Remaining challenges in the treatment of tyrosinemia from the clinician's viewpoint. Adv Exp Med Biol. 2017;959:205-13.

49. Malik S, NiMhurchadha S, Jackson C, Eliasson L, Weinman J, Roche S, Walter J. Treatment adherence in type 1 hereditary tyrosinaemia (HT1): a mixed-method investigation into the beliefs, attitudes and behaviour of adolescent patients, their families and their health-care team. JIMD Rep. 2015;18:13-22.

50. Masurel-Paulet A, Poggi-Bach J, Rolland MO, Bernard O, Guffon N, Dobbelaere D, Sarles J, de Baulny HO, Touati G. NTBC treatment in tyrosinaemia type I: long-term outcome in French patients. J Inherit Metab Dis. 2008;31:81-7.

51. Couce ML, Dalmau J, del Toro M, Pintos-Morell G, AldamizEchevarria L. Spanish working group on tyrosinemia type, 1, tyrosinemia type 1 in Spain: mutational analysis, treatment and long-term outcome. Pediatr Int. 2011;53:985-9.

52. Honar N, Shakibazad N, Serati Shirazi Z, Dehghani SM, Inaloo S. Neurological crises after discontinuation of nitisinone (NTBC) treatment in tyrosinemia. Iran J Child Neurol. 2017;11:66-70.

53. Onenli Mungan N, Yildizdas D, Kor D, Horoz OO, Incecik F, Oktem M, Sander J. Tyrosinemia type 1 and irreversible neurologic crisis after one month discontinuation of nitisone. Metab Brain Dis. 2016;31:1181-3.

54. Ucar HK, Tumgor G, Kor D, Kardas F, Mungan NO. A case report of a very rare association of tyrosinemia type I and pancreatitis mimicking neurologic crisis of tyrosinemia type I. Balkan Med J. 2016;33:370-2.

55. Aktuglu-Zeybek AC, Kiykim E, Cansever MS. Hereditary tyrosinemia type 1 in Turkey. Adv Exp Med Biol. 2017;959:157-72.

56. Schlump JU, Perot C, Ketteler K, Schiff M, Mayatepek E, Wendel U, Spiekerkoetter U. Severe neurological crisis in a patient with hereditary tyrosinaemia type I after interruption of NTBC treatment. J Inherit Metab Dis. 2008;31(Suppl 2):223.

57. Grompe M, Lindstedt S, Al-Dhalimy M, Kennaway NG, Papaconstantinou J, Torres-Ramos CA, Ou CN, Finegold M. Pharmacological correction of neonatal lethal hepatic dysfunction in a murine model of hereditary tyrosinaemia type I. Nat Genet. 1995;10:453-60.

58. Phornphutkul C, Introne WJ, Perry MB, Bernardini I, Murphey MD, Fitzpatrick DL, Anderson PD, Huizing M, Anikster Y, Gerber LH, Gahl WA. Natural history of alkaptonuria. N Engl J Med. 2002;347:2111-21

59. Ranganath LR, Jarvis JC, Gallagher JA. Recent advances in management of alkaptonuria (invited review; best practice article). J Clin Pathol. 2013;66:367-73.

60. Introne WJ, Perry MB, Troendle J, Tsilou E, Kayser MA, Suwannarat P, O'Brien KE, Bryant J, Sachdev V, Reynolds JC, Moylan E, Bernardini I, Gahl WA. A 3-year randomized therapeutic trial of nitisinone in alkaptonuria. Mol Genet Metab. 2011;103:307-14.

61. Ranganath LR, Milan AM, Hughes AT, Dutton JJ, Fitzgerald R, Briggs MC, Bygott H, Psarelli EE, Cox TF, Gallagher JA, Jarvis JC, van Kan C, Hall AK, Laan D, Olsson B, Szamosi J, Rudebeck M, Kullenberg T, Cronlund A, Svensson L, Junestrand C,
Ayoob H, Timmis OG, Sireau N, Le Quan Sang KH, Genovese F, Braconi D, Santucci A, Nemethova M, Zatkova A, McCaffrey J, Christensen P, Ross G, Imrich R, Rovensky J. Suitability of nitisinone in alkaptonuria 1 (SONIA 1): an international, multicentre, randomised, open-label, no-treatment controlled, parallel-group, dose-response study to investigate the effect of once daily nitisinone on 24-h urinary homogentisic acid excretion in patients with alkaptonuria after 4 weeks of treatment. Ann Rheum Dis. 2016;75:362-7.

62. Griffin R, Psarelli EE, Cox TF, Khedr M, Milan AM, Davison AS, Hughes AT, Usher JL, Taylor S, Loftus N, Daroszewska A, West E, Jones A, Briggs M, Fisher M, McCormick M, Judd S, Vinjamuri S, Sireau N, Dillon JP, Devine JM, Hughes G, Harrold J, Barton GJ, Jarvis JC, Gallagher JA, Ranganath LR. Data on items of AKUSSI in Alkaptonuria collected over three years from the United Kingdom National Alkaptonuria Centre and the impact of nitisinone. Data Brief. 2018;20:1620-8.

63. Ranganath LR, Khedr M, Milan AM, Davison AS, Hughes AT, Usher JL, Taylor S, Loftus N, Daroszewska A, West E, Jones A, Briggs M, Fisher M, McCormick M, Judd S, Vinjamuri S, Griffin R, Psarelli EE, Cox TF, Sireau N, Dillon JP, Devine JM, Hughes G, Harrold J, Barton GJ, Jarvis JC, Gallagher JA. Nitisinone arrests ochronosis and decreases rate of progression of Alkaptonuria: Evaluation of the effect of nitisinone in the United Kingdom National Alkaptonuria Centre. Mol Genet Metab. 2018;125:127-34.

64. Yang H, Al-Hertani W, Cyr D, Laframboise R, Parizeault G, Wang SP, Rossignol F, Berthier MT, Giguere Y, Waters PJ, Mitchell GA. Quebec NTBC Study Group, Hypersuccinylacetonaemia and normal liver function in maleylacetoacetate isomerase deficiency. J Med Genet. 2017;54:241-7.

65. Fernandez-Canon JM, Baetscher MW, Finegold M, Burlingame T, Gibson KM, Grompe M. Maleylacetoacetate isomerase (MAAI/GSTZ)-deficient mice reveal a glutathione-dependent nonenzymatic bypass in tyrosine catabolism. Mol Cell Biol. 2002;22:4943-51.

66. Niederwieser A, Matasovic A, Tippett P, Danks DM. A new sulfur amino acid, named hawkinsin, identified in a baby with transient tyrosinemia and her mother. Clin Chim Acta. 1977;76:345-56.

67. Tomoeda K, Awata H, Matsuura T, Matsuda I, Ploechl E, Milovac T, Boneh A, Scott CR, Danks DM, Endo F. Mutations in the 4-hydroxyphenylpyruvic acid dioxygenase gene are responsible for tyrosinemia type III and hawkinsinuria. Mol Genet Metab. 2000;71:506-10.

68. Brownlee JM, Heinz B, Bates J, Moran GR. Product analysis and inhibition studies of a causative Asn to Ser variant of 4-hydroxyphenylpyruvate dioxygenase suggest a simple route to the treatment of Hawkinsinuria. Biochemistry. 2010;49:7218-26.

69. Danks DM, Tippett P, Rogers J. A new form of prolonged transient tyrosinemia presenting with severe metabolic acidosis. Acta Paediatr Scand. 1975;64:209-14.

70. Wilcken B, Hammond JW, Howard N, Bohane T, Hocart C, Halpern B. Hawkinsinuria: a dominantly inherited defect of tyrosine metabolism with severe effects in infancy. N Engl J Med. 1981;305:865-8.

71. Borden M, Holm J, Leslie J, Sweetman L, Nyhan WL, Fleisher L, Nadler H, Lewis D, Scott CR. Hawkinsinuria in two families. Am J Med Genet. 1992;44:52-6.

72. Lehnert W, Stogmann W, Engelke U, Wevers RA, van den Berg GB. Long-term follow up of a new case of hawkinsinuria. Eur J Pediatr. 1999;158:578-82.

73. Thodi G, Schulpis KH, Dotsikas Y, Pavlides C, Molou E, Chatzidaki M, Triantafylli O, Loukas YL. Hawkinsinuria in two unrelated Greek newborns: identification of a novel variant, 
biochemical findings and treatment. J Pediatr Endocrinol Metab. 2016;29:15-20.

74. Harding CO, Winn SR, Gibson KM, Arning E, Bottiglieri T, Grompe M. Pharmacologic inhibition of L-tyrosine degradation ameliorates cerebral dopamine deficiency in murine phenylketonuria (PKU). J Inherit Metab Dis. 2014;37:735-43.

75. van Vliet D, Bruinenberg VM, Mazzola PN, van Faassen MH, de Blaauw P, Kema IP, Heiner-Fokkema MR, van Anholt RD, van der Zee EA, van Spronsen FJ. Large neutral amino acid supplementation exerts its effect through three synergistic mechanisms: proof of principle in phenylketonuria mice. PLoS One. 2015;10:e0143833.

76. Diamond A, Prevor MB, Callender G, Druin DP. Prefrontal cortex cognitive deficits in children treated early and continuously for PKU. Monogr Soc Res Child Dev. 1997;62:208.

77. Luciana M, Sullivan J, Nelson CA. Associations between phenylalanine-to-tyrosine ratios and performance on tests of neuropsychological function in adolescents treated early and continuously for phenylketonuria. Child Dev. 2001;72:1637-52.

78. Sharman R, Sullivan K, Young R, McGill J. A preliminary investigation of the role of the phenylalanine:tyrosine ratio in children with early and continuously treated phenylketonuria: toward identification of "safe" levels. Dev Neuropsychol. 2010;35:57-65.

79. Jahja R, Huijbregts SC, de Sonneville LM, van der Meere JJ, van Spronsen FJ. Neurocognitive evidence for revision of treatment targets and guidelines for phenylketonuria. J Pediatr. 2014;164:899.e2.

80. Lock EA, Gaskin P, Ellis MK, Robinson M, Provan WM, Smith LL. The effect of a low-protein diet and dietary supplementation of threonine on tyrosine and 2-(2-nitro-4-trifluoromethylbenzoyl) cyclohexane-1,3-dione-induced corneal lesions, the extent of tyrosinemia, and the activity of enzymes involved in tyrosine catabolism in the rat. Toxicol Appl Pharmacol. 1998;150:125-32.

81. Lock EA, Gaskin P, Ellis M, Provan WM, Smith LL. Tyrosinemia produced by 2-(2-nitro-4-trifluoromethylbenzoyl)-cyclohexane1,3-dione (NTBC) in experimental animals and its relationship to corneal injury. Toxicol Appl Pharmacol. 2006;215:9-16.

82. Schiff M, Broue P, Chabrol B, De Laet C, Habes D, Mention K, Sarles J, Spraul A, Valayannopoulos V, Ogier de Baulny H. French-Belgian study group for, HT-1, Heterogeneity of followup procedures in French and Belgian patients with treated hereditary tyrosinemia type 1: results of a questionnaire and proposed guidelines. J Inherit Metab Dis. 2012;35:823-9.

83. Scott CR. The genetic tyrosinemias. Am J Med Genet C Semin Med Genet. 2006;142C:121-6.

84. Ahmad S, Teckman JH, Lueder GT. Corneal opacities associated with NTBC treatment. Am J Ophthalmol. 2002;134:266-8.

85. Wisse RP, Wittebol-Post D, Visser G, van der Lelij A. Corneal depositions in tyrosinaemia type I during treatment with Nitisinone. BMJ Case Rep. 2012;2012:006301.

86. Schauwvlieghe PP, Jaeken J, Kestelyn P, Claerhout I. Confocal microscopy of corneal crystals in a patient with hereditary tyrosinemia type I, treated with NTBC. Cornea. 2013;32:91-4.

87. Gulmez Sevim D, Gumus K, Cavanagh HD. Corneal pseudodendritic lesions masquerading as herpetic keratitis in a patient with tyrosinemia type I. Eye Contact Lens. 2017;43:e9.

88. Gissen P, Preece MA, Willshaw HA, McKiernan PJ. Ophthalmic follow-up of patients with tyrosinaemia type I on NTBC. J Inherit Metab Dis. 2003;26:13-6.

89. Wilson CJ, Van Wyk KG, Leonard JV, Clayton PT. Phenylalanine supplementation improves the phenylalanine profile in tyrosinaemia. J Inherit Metab Dis. 2000;23:677-83.

90. Daly A, Gokmen-Ozel H, MacDonald A, Preece MA, Davies P, Chakrapani A, McKiernan P. Diurnal variation of phenylalanine concentrations in tyrosinaemia type 1: should we be concerned? J Hum Nutr Diet. 2012;25:111-6.

91. van Vliet D, van Dam E, van Rijn M, Derks TG, VenemaLiefaard G, Hitzert MM, Lunsing RJ, Heiner-Fokkema MR, van Spronsen FJ. Infants with tyrosinemia type 1: should phenylalanine be supplemented? JIMD Rep. 2015;18:117-24.

92. van Dam E, Daly A, Venema-Liefaard G, van Rijn M, Derks TGJ, McKiernan PJ, Rebecca Heiner-Fokkema M, MacDonald A, van Spronsen FJ. What is the best blood sampling time for metabolic control of phenylalanine and tyrosine concentrations in tyrosinemia type 1 patients? JIMD Rep. 2017;36:49-57.

93. van Ginkel WG, van Vliet D, Burgerhof JGM, de Blaauw P, Rubio Gozalbo ME, Heiner-Fokkema MR, van Spronsen FJ. Presumptive brain influx of large neutral amino acids and the effect of phenylalanine supplementation in patients with Tyrosinemia type 1. PLoS One. 2017;12:e0185342.

94. Blau N, Duran M, Blaskovics ME. Physician's guide to the laboratory diagnosis of metabolic diseases. London: Chapman \& Hall; 1996.

95. Alobaidy H, Barkaoui E. Experience of a single center in NTBC use in management of hereditary tyrosinemia type I in libya. Iran J Pediatr. 2015;25:e3608

96. Jorquera R, Tanguay RM. The mutagenicity of the tyrosine metabolite, fumarylacetoacetate, is enhanced by glutathione depletion. Biochem Biophys Res Commun. 1997;232:42-8.

97. Jorquera R, Tanguay RM. Fumarylacetoacetate, the metabolite accumulating in hereditary tyrosinemia, activates the ERK pathway and induces mitotic abnormalities and genomic instability. Hum Mol Genet. 2001;10:1741-52.

98. Bergeron A, Jorquera R, Orejuela D, Tanguay RM. Involvement of endoplasmic reticulum stress in hereditary tyrosinemia type I. J Biol Chem. 2006;281:5329-34.

99. Tanguay RM, Angileri F, Vogel A. Molecular pathogenesis of liver injury in hereditary tyrosinemia 1. Adv Exp Med Biol. 2017;959:49-64.

100. Russo PA, Mitchell GA, Tanguay RM. Tyrosinemia: a review. Pediatr Dev Pathol. 2001;4:212-21.

101. Kvittingen EA. Hereditary tyrosinemia type I-an overview. Scand J Clin Lab Investig Suppl. 1986;184:27-34.

102. Kvittingen EA. Tyrosinaemia type I-an update. J Inherit Metab Dis. 1991;14:554-62.

103. Murcia FJ, Vazquez J, Gamez M, Lopez Santamaria M, de la Vega A, Diaz MC, Jara P, Tovar J. Liver transplantation in type I tyrosinemia. Transplant Proc. 1995;27:2301-2.

104. Seda Neto J, Leite KM, Porta A, Fonseca EA, Feier FH, Pugliese R, Miura IK, Chapchap P, Porta G. HCC prevalence and histopathological findings in liver explants of patients with hereditary tyrosinemia type 1. Pediatr Blood Cancer. 2014;61:1584-9.

105. Imseis EM, Bynon JS, Thornhill C. Case of hepatocellular carcinoma in a patient with hereditary tyrosinemia in the post-newborn screening era. World J Hepatol. 2017;9:487-90.

106. Flye MW, Riely CA, Hainline BE, Sassa S, Gusberg RJ, Blakemore KJ, Barwick KW, Horwich AL. The effects of early treatment of hereditary tyrosinemia type I in infancy by orthotopic liver transplantation. Transplantation. 1990;49:916-21.

107. Freese DK, Tuchman M, Schwarzenberg SJ, Sharp HL, Rank JM, Bloomer JR, Ascher NL, Payne WD. Early liver transplantation is indicated for tyrosinemia type I. J Pediatr Gastroenterol Nutr. 1991;13:10-5.

108. Riudor E, Ribes A, Lloret J, Friden J, Holme E, Jakobs C, Martinez Ibanez V. Liver transplantation in two children with tyrosinaemia type I: biochemical aspects. J Inherit Metab Dis. 1991;14:281-4.

109. Salt A, Barnes ND, Rolles K, Calne RY, Clayton PT, Leonard $\mathrm{JV}$. Liver transplantation in tyrosinaemia type 1: the dilemma of timing the operation. Acta Paediatr. 1992;81:449-52. 
110. Perez-Cerda C, Merinero B, Sanz P, Castro M, Gangoiti J, Garcia MJ, Diaz M, Medina E, Ugarte M. Liver transplantation in nine Spanish patients with tyrosinaemia type I. J Inherit Metab Dis. 1995;18:119-22.

111. Joshi SN, Venugopalan P. Experience with NTBC therapy in hereditary tyrosinaemia type I: an alternative to liver transplantation. Ann Trop Paediatr. 2004;24:259-65.

112. McKiernan PJ. Nitisinone in the treatment of hereditary tyrosinaemia type 1. Drugs. 2006;66:743-50.

113. Nobili V, Jenkner A, Francalanci P, Castellano A, Holme E, Callea F, Dionisi-Vici C. Tyrosinemia type 1: metastatic hepatoblastoma with a favorable outcome. Pediatrics. 2010;126:235.

114. van Spronsen FJ, Bijleveld CM, van Maldegem BT, Wijburg FA. Hepatocellular carcinoma in hereditary tyrosinemia type I despite 2-(2 nitro-4-3 trifluoro- methylbenzoyl)-1, 3-cyclohexanedione treatment. J Pediatr Gastroenterol Nutr. 2005;40:90-3.

115. Koelink CJ, van Hasselt P, van der Ploeg A, van den HeuvelEibrink MM, Wijburg FA, Bijleveld CM, van Spronsen FJ. Tyrosinemia type I treated by NTBC: how does AFP predict liver cancer? Mol Genet Metab. 2006;89:310-5.

116. Dursun A, Ozgul RK, Sivri S, Tokatli A, Guzel A, Mesci L, Kilic M, Aliefendioglu D, Ozcay F, Gunduz M, Coskun T. Mutation spectrum of fumarylacetoacetase gene and clinical aspects of tyrosinemia type I disease. JIMD Rep. 2011;1:17-21.

117. Bahador A, Dehghani SM, Geramizadeh B, Nikeghbalian S, Bahador M, Malekhosseini SA, Kazemi K, Salahi H. Liver transplant for children with hepatocellular carcinoma and hereditary tyrosinemia type 1. Exp Clin Transplant. 2015;13:329-32.

118. van Ginkel WG, Gouw AS, van der Jagt EJ, de Jong KP, Verkade $\mathrm{HJ}$, van Spronsen FJ. Hepatocellular carcinoma in tyrosinemia type 1 without clear increase of AFP. Pediatrics. 2015;135:749.

119. Gokay S, Ustkoyuncu PS, Kardas F, Kendirci M. The outcome of seven patients with hereditary tyrosinemia type 1 . J Pediatr Endocrinol Metab. 2016;29:1151-7.

120. McKiernan P. Liver transplantation for hereditary tyrosinaemia type 1 in the United Kingdom. Adv Exp Med Biol. 2017;959:85-91.

121. Alvarez F, Mitchell GA. Tyrosinemia and liver transplantation: experience at CHU Sainte-Justine. Adv Exp Med Biol. 2017;959:67-73.

122. McKiernan PJ, Preece MA, Chakrapani A. Outcome of children with hereditary tyrosinaemia following newborn screening. Arch Dis Child. 2015;100:738-41.

123. Halac U, Dubois J, Mitchell GA. The liver in tyrosinemia type I: clinical management and course in Quebec. Adv Exp Med Biol. 2017;959:75-83.

124. van Ginkel WG, Pennings JP, van Spronsen FJ. Liver cancer in tyrosinemia type 1. Adv Exp Med Biol. 2017;959:101-9.

125. Grompe M, Overturf K, Al-Dhalimy M, Finegold M. Therapeutic trials in the murine model of hereditary tyrosinaemia type I: a progress report. J Inherit Metab Dis. 1998;21:518-31.

126. Al-Dhalimy M, Overturf K, Finegold M, Grompe M. Long-term therapy with NTBC and tyrosine-restricted diet in a murine model of hereditary tyrosinemia type I. Mol Genet Metab. 2002;75:38-45

127. Luijerink MC, Jacobs SM, van Beurden EA, Koornneef LP, Klomp LW, Berger R, van den Berg IE. Extensive changes in liver gene expression induced by hereditary tyrosinemia type I are not normalized by treatment with 2-(2-nitro4-trifluoromethylbenzoyl)-1,3-cyclohexanedione (NTBC). J Hepatol. 2003;39:901-9.

128. Hanauske-Abel HM, Popowicz A, Remotti H, Newfield RS, Levy J. Tyrosinemia I, a model for human diseases mediated by 2-oxoacid-utilizing dioxygenases: hepatotoxin suppression by NTBC does not normalize hepatic collagen metabolism. J Pediatr Gastroenterol Nutr. 2002;35:73-8.
129. Baumann U, Duhme V, Auth MK, McKiernan PJ, Holme E. Lectin-reactive alpha-fetoprotein in patients with tyrosinemia type I and hepatocellular carcinoma. J Pediatr Gastroenterol Nutr. 2006;43:77-82.

130. Sun MS, Hattori S, Kubo S, Awata H, Matsuda I, Endo F. A mouse model of renal tubular injury of tyrosinemia type 1: development of de Toni Fanconi syndrome and apoptosis of renal tubular cells in Fah/Hpd double mutant mice. J Am Soc Nephrol. 2000;11:291-300.

131. Roth KS, Spencer PD, Higgins ES, Spencer RF. Effects of succinylacetone on methyl alpha-D-glucoside uptake by the rat renal tubule. Biochim Biophys Acta. 1985;820:140-6.

132. Santra S, Preece MA, Hulton SA, McKiernan PJ. Renal tubular function in children with tyrosinaemia type I treated with nitisinone. J Inherit Metab Dis. 2008;31:399-402.

133. Halvorsen S, Gjessing LR. Studies on tyrosinosis: 1, effect of low-tyrosine and low-phenylalanine diet. Br Med J. 1964;2:1171-3.

134. Kvittingen EA, Talseth T, Halvorsen S, Jakobs C, Hovig T, Flatmark A. Renal failure in adult patients with hereditary tyrosinaemia type I. J Inherit Metab Dis. 1991;14:53-62.

135. Shoemaker LR, Strife CF, Balistreri WF, Ryckman FC. Rapid improvement in the renal tubular dysfunction associated with tyrosinemia following hepatic replacement. Pediatrics. 1992;89:251-5.

136. Pronicka E, Rowinska E, Bentkowski Z, Zawadzki J, Holme E, Lindstedt $S$. Treatment of two children with hereditary tyrosinaemia type I and long-standing renal disease with a 4-hydroxyphenylpyruvate dioxygenase inhibitor (NTBC). J Inherit Metab Dis. 1996;19:234-8.

137. Dehghani SM, Haghighat M, Imanieh MH, Karamnejad H, Malekpour A. Clinical and para clinical findings in the children with tyrosinemia referring for liver transplantation. Int J Prev Med. 2013;4:1380-5.

138. Bartlett DC, Lloyd C, McKiernan PJ, Newsome PN. Early nitisinone treatment reduces the need for liver transplantation in children with tyrosinaemia type 1 and improves post-transplant renal function. J Inherit Metab Dis. 2014;37:745-52.

139. Maiorana A, Malamisura M, Emma F, Boenzi S, Di Ciommo VM, Dionisi-Vici C. Early effect of NTBC on renal tubular dysfunction in hereditary tyrosinemia type 1 . Mol Genet Metab. 2014;113:188-93.

140. Maiorana A, Dionisi-Vici C. NTBC and correction of renal dysfunction. Adv Exp Med Biol. 2017;959:93-100.

141. van Ginkel WG, Jahja R, Huijbregts SCJ, van Spronsen FJ. Neurological and neuropsychological problems in tyrosinemia type i patients. Adv Exp Med Biol. 2017;959:111-22.

142. De Laet C, Munoz VT, Jaeken J, Francois B, Carton D, Sokal EM, Dan B, Goyens PJ. Neuropsychological outcome of NTBCtreated patients with tyrosinaemia type 1. Dev Med Child Neurol. 2011;53:962-4.

143. Thimm E, Richter-Werkle R, Kamp G, Molke B, Herebian D, Klee D, Mayatepek E, Spiekerkoetter U. Neurocognitive outcome in patients with hypertyrosinemia type I after long-term treatment with NTBC. J Inherit Metab Dis. 2012;35:263-8.

144. van Ginkel WG, Jahja R, Huijbregts SC, Daly A, MacDonald A, De Laet C, Cassiman D, Eyskens F, Korver-Keularts IM, Goyens PJ, McKiernan PJ, van Spronsen FJ. Neurocognitive outcome in tyrosinemia type 1 patients compared to healthy controls. Orphanet J Rare Dis. 2016;11:5.

145. Bendadi F, de Koning TJ, Visser G, Prinsen HC, de Sain MG, Verhoeven-Duif N, Sinnema G, van Spronsen FJ, van Hasselt PM. Impaired cognitive functioning in patients with tyrosinemia type I receiving nitisinone. J Pediatr. 2014;164:398-401.

146. Garcia MI, de la Parra A, Arias C, Arredondo M, Cabello JF. Long-term cognitive functioning in individuals with tyrosinemia 
type 1 treated with nitisinone and protein-restricted diet. Mol Genet Metab Rep. 2017;11:12-6.

147. Walker H, Pitkanen M, Rahman Y, Barrington SF. Three cases of hereditary tyrosinaemia type 1: neuropsychiatric outcomes and brain imaging following treatment with NTBC. JIMD Rep. 2018;40:97-103.

148. Pohorecka M, Biernacka M, Jakubowska-Winecka A, Biernacki M, Kusmierska K, Kowalik A, Sykut-Cegielska J. Behavioral and intellectual functioning in patients with tyrosinemia type I. Pediatr Endocrinol Diabetes Metab. 2012;18:96-100.

149. Sener RN. Brain magnetic resonance imaging in tyrosinemia. Acta Radiol. 2005;46:618-20.

150. Sener RN. Tyrosinemia: computed tomography, magnetic resonance imaging, diffusion magnetic resonance imaging, and proton spectroscopy findings in the brain. J Comput Assist Tomogr. 2005;29:323-5.

151. Hillgartner MA, Coker SB, Koenig AE, Moore ME, Barnby E, MacGregor GG. Tyrosinemia type I and not treatment with NTBC causes slower learning and altered behavior in mice. J Inherit Metab Dis. 2016.

152. Moore ME, Koenig AE, Hillgartner MA, Otap CC, Barnby E, MacGregor GG. Abnormal social behavior in mice with tyrosinemia type $\mathrm{I}$ is associated with an increase of myelin in the cerebral cortex. Metab Brain Dis. 2017;32:1829-41.

153. Simons A, Eyskens F, Raets E, Glazemakers I, van West D. Girl with tyrosinemia type $\mathrm{i}$ and executive dysfunctions treated with methylphenidate: a case report. J Inborn Errors Metab Screen. 2018;1-3.

154. Thimm E, Herebian D, Assmann B, Klee D, Mayatepek E, Spiekerkoetter U. Increase of CSF tyrosine and impaired serotonin turnover in tyrosinemia type I. Mol Genet Metab. 2011;102:122-5.

155. Edwards MA, Green A, Colli A, Rylance G. Tyrosinaemia type I and hypertrophic obstructive cardiomyopathy. Lancet. 1987;1:1437-8

156. Mohan N, McKiernan P, Preece MA, Green A, Buckels J, Mayer $\mathrm{AD}$, Kelly DA. Indications and outcome of liver transplantation in tyrosinaemia type 1. Eur J Pediatr. 1999;158(Suppl 2):49.

157. Andre N, Roquelaure B, Jubin V, Ovaert C. Successful treatment of severe cardiomyopathy with NTBC in a child with tyrosinaemia type I. J Inherit Metab Dis. 2005;28:103-6.

158. Arora N, Stumper O, Wright J, Kelly DA, McKiernan PJ. Cardiomyopathy in tyrosinaemia type I is common but usually benign. J Inherit Metab Dis. 2006;29:54-7.

159. Mohamed S, Kambal MA, Al Jurayyan NA, Al-Nemri A, Babiker A, Hasanato R, Al-Jarallah AS. Tyrosinemia type 1: a rare and forgotten cause of reversible hypertrophic cardiomyopathy in infancy. BMC Res Notes. 2013;6:362.

160. Nissenkorn A, Korman SH, Vardi O, Levine A, Katzir Z, Ballin A, Lerman-Sagie T. Carnitine-deficient myopathy as a presentation of tyrosinemia type I. J Child Neurol. 2001;16:642-4.

161. Baumann U, Preece MA, Green A, Kelly DA, McKiernan PJ. Hyperinsulinism in tyrosinaemia type I. J Inherit Metab Dis. 2005;28:131-5.

162. Garcia Segarra N, Roche S, Imbard A, Benoist JF, Greneche MO, Davit-Spraul A, Ogier de Baulny H. Maternal and fetal tyrosinemia type I. J Inherit Metab Dis. 2010;33(Suppl 3):507.
163. Vanclooster A, Devlieger R, Meersseman W, Spraul A, Kerckhove KV, Vermeersch P, Meulemans A, Allegaert K, Cassiman D. Pregnancy during nitisinone treatment for tyrosinaemia type I: first human experience. JIMD Rep. 2012;5:27-33.

164. Kassel R, Sprietsma L, Rudnick DA. Pregnancy in an NTBCtreated patient with hereditary tyrosinemia type I. J Pediatr Gastroenterol Nutr. 2015;60:5.

165. Hickey RD, Mao SA, Glorioso J, Lillegard JB, Fisher JE, Amiot B, Rinaldo P, Harding CO, Marler R, Finegold MJ, Grompe M, Nyberg SL. Fumarylacetoacetate hydrolase deficient pigs are a novel large animal model of metabolic liver disease. Stem Cell Res. 2014;13:144-53.

166. Sagonowsky E. The 20 most expensive pharmacy drugs in 2018 , featuring names big and small. 2018. www.fiercepharma.com.

167. Canadian Agency for Drugs and Technologies in Health, Pharmacoeconomic Review Report: Nitisinone (Nitisinone Tablets): (Cycle Pharmaceuticals Ltd.): Indication: For the treatment of patients with hereditary tyrosinemia type 1 in combination with dietary restriction of tyrosine and phenylalanine. 2018.

168. Zorginstituut Nederland, Geneesmiddelen: Nitisinon 2019. www. farmacotherapeutischkompas.nl

169. Simoncelli M, Samson J, Bussieres JF, Lacroix J, Dorais M, Battista R, Perreault S. Cost-consequence analysis of nitisinone for treatment of tyrosinemia type I. Can J Hosp Pharm. 2015;68:210-7.

170. Szegedi M, Zelei T, Arickx F, Bucsics A, Cohn-Zanchetta E, Furst J, Kamusheva M, Kawalec P, Petrova G, Slaby J, Stawowczyk E, Vocelka M, Zechmeister-Koss I, Kalo Z, Molnar MJ. The European challenges of funding orphan medicinal products. Orphanet J Rare Dis. 2018;13.

171. Schuller Y, Arends M, Korver S, Langeveld M, Hollak CEM. Adaptive pathway development for Fabry disease: a clinical approach. Drug Discov Today. 2018;23:1251-7.

172. Hostetter MK, Levy HL, Winter HS, Knight GJ, Haddow JE. Evidence for liver disease preceding amino acid abnormalities in hereditary tyrosinemia. N Engl J Med. 1983;308:1265-7.

173. Ruppert S, Kelsey G, Schedl A, Schmid E, Thies E, Schutz G. Deficiency of an enzyme of tyrosine metabolism underlies altered gene expression in newborn liver of lethal albino mice. Genes Dev. 1992;6:1430-43.

174. Rossidis AC, Stratigis JD, Chadwick AC, Hartman HA, Ahn NJ, Li H, Singh K, Coons BE, Li L, Lv W, Zoltick PW, Alapati D, Zacharias W, Jain R, Morrisey EE, Musunuru K, Peranteau WH. In utero CRISPR-mediated therapeutic editing of metabolic genes. Nat Med. 2018;24:1513-8.

175. Overturf K, Al-Dhalimy M, Ou CN, Finegold M, Tanguay R, Lieber A, Kay M, Grompe M. Adenovirus-mediated gene therapy in a mouse model of hereditary tyrosinemia type I. Hum Gene Ther. 1997;8:513-21.

176. Hickey RD, Nicolas CT, Allen K, Mao S, Elgilani F, Glorioso J, Amiot B, VanLith C, Guthman R, Du Z, Chen H, Harding CO, Kaiser RA, Nyberg SL, Lillegard JB. Autologous gene and cell therapy provides safe and long-term curative therapy in a large pig model of hereditary tyrosinemia type 1 . Cell Transplant. 2019;28:79-88. 